\title{
ANALISIS HUBUNGAN ANTARA MOTIVASI BELAJAR DENGAN HASIL BELAJAR SISWA PADA SEKOLAH DASAR NEGERI 3 ALLAKUANG KECAMATAN MARITENGNGAE KABUPATEN SIDENRENG RAPPANG
}

\author{
DAMIS DAN MUHAJIS \\ Fakultas Agama Islam, Universitas Indonesia Timur Makassar \\ Jl. Rappocini Raya No. 171-173 Kota Makassar 90222 \\ Email: damis3870@gmail.com
}

\begin{abstract}
:
This study aims to find out and analyze the relationship between learning motivation and student learning outcomes at State Elementary School 3 Allakuang, Maritengngae District, Sidenreng Rappang Regency. This research is quantitative research by distributing questionnaires to 44 students. This study used a simple linear regression analysis method to determine the effect of learning motivation on student learning achievement, and correlation coefficient to measure the relationship between one variable and another variable. The results showed that motivation had a significant influence on student learning achievement and there was a positive relationship between learning motivation towards student learning outcomes, but the relationship was weak because the results of the discussion showed a relationship between learning motivation and student learning outcomes of 0.10 or $10 \%$.
\end{abstract}

Keywords: Motivation to learn, learning outcomes

\section{PENDAHULUAN}

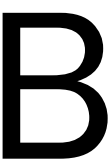

erbicara tentang korelasi motivasi belajar terhadap hasil belajar siswa, setiap pembelajaran pada dasarnya memiliki karakteristik tersendiri. Karakteristik tersebut menyebabkan suatu metode berbeda dengan metode lainnya baik secara konseptual maupun operasional. Sehubungan dengan hal tersebut di atas, maka untuk menetapkan strategi guru dalam memotivasi siswa dalam proses pengajaran harus disesuaikan dengan kondisi dan suasana kelas, jumlah anak juga mempengaruhi kondisi pengajaran yang ditetapkan.

Syaiful Bahri Djamarah dan Azwan Zain dalam mengutip pendapat Roestiyah N.K berpendapat bahwa:

Dalam kegiatan belajar mengajar guru harus mampu memotivasi anak didik agar anak dapat belajar secara efektif dan efisien, mengenai tujuan yang diharapkan.

Salah satu langkah untuk memilih strategi motivasi itu adalah harus menguasai teknik-teknik penyajian atau biasanya disebut metode mengajar. Dengan demikian metode mengajar adalah strategi pengajaran sebagai alat untuk mencapai tujuan yang diharapkan.

Dalam dunia pendidikan, terutama dalam kegiatan belajar, bahwa kelangsungan dan keberhasilan proses belajar mengajar bukan hanya dipengaruhi oleh faktor intelektual saja, melainkan juga oleh faktor-faktor nonintelektual lain yang tidak kalah penting dalam 
menentukan hasil belajar seseorang, salah satunya adalah kemampuan seseorang siswa untuk memotivasi dirinya. Mengutip pendapat Daniel Goleman (2004: 44), kecerdasan intelektual (IQ) hanya menyumbang $20 \%$ bagi kesuksesan, sedangkan $80 \%$ adalah sumbangan faktor kekuatan-kekuatan lain, diantaranya adalah kecerdasan emosional atau Emotional Quotient (EQ) yakni kemampuan memotivasi diri sendiri, mengatasi frustasi, mengontrol desakan hati, mengatur suasana hati (mood), berempati serta kemampuan bekerja sama.

Motivasi sangat penting artinya dalam kegiatan belajar, sebab adanya motivasi mendorong semangat belajar dan sebaliknya kurang adanya motivasi akan melemahkan semangat belajar. Motivasi merupakan syarat mutlak dalam belajar; seorang siswa yang belajar tanpa motivasi (atau kurang motivasi) tidak akan berhasil dengan maksimal.

Motivasi memegang peranan yang amat penting dalam belajar, Maslow dengan teori kebutuhannya, menggambarkan hubungan hirarkhis dan berbagai kebutuhan, di ranah kebutuhan pertama merupakan dasar untuk timbul kebutuhan berikutnya. Jika kebutuhan pertama telah terpuaskan, barulah manusia mulai ada keinginan untuk memuaskan kebutuhan yang selanjutnya. Pada kondisi tertentu akan timbul kebutuhan yang tumpang tindih, contohnya adalah orang ingin makan bukan karena lapar tetapi karena ada kebutuhan lain yang mendorongnya. Jika suatu kebutuhan telah terpenuhi atau perpuaskan, itu tidak berarti bahwa kebutuhan tesebut tidak akan muncul lagi untuk selamanya, tetapi kepuasan itu hanya untuk sementara waktu saja. Manusia yang dikuasai oleh kebutuhan yang tidak terpuaskan akan termotivasi untuk melakukan kegiatan guna memuaskan kebutuhan tersebut.

Dalam implikasinya pada dunia belajar, siswa atau pelajar yang lapar tidak akan termotivasi secara penuh dalam belajar. Setelah kebutuhan yang bersifat fisik terpenuhi, maka meningkat pada kebutuhan tingkat berikutnya adalah rasa aman. Sebagai contoh adalah seorang siswa yang merasa terancam atau dikucilkan baik oleh siswa lain mapun gurunya, maka ia tidak akan termotivasi dengan baik dalam belajar. Ada kebutuhan yang disebut harga diri, yaitu kebutuhan untuk merasa dipentingkan dan dihargai. Seseorang siswa yang telah terpenuhi kebutuhan harga dirinya, maka dia akan percaya diri, merasa berharga, marasa kuat, merasa mampu/bisa, merasa berguna dalam didupnya. Kebutuhan yang paling utama atau tertinggi yaitu jika seluruh kebutuhan secara individu terpenuhi maka akan merasa bebas untuk menampilkan seluruh potensinya secara penuh. Dasarnya untuk mengaktualisasikan sendiri meliputi kebutuhan menjadi tahu, mengerti untuk memuaskan aspek-aspek kognitif yang paling mendasar.

Guru sebagai seorang pendidik harus tahu apa yang diinginkan oleh para sisiwanya. Seperti kebutuhan untuk berprestasi, karena setiap siswa memiliki kebutuhan untuk berprestasi yang berbeda satu sama lainnya. Tidak sedikit siswa yang memiliki motivasi berprestasi yang rendah, mereka cenderung takut gagal dan tidak mau menanggung resiko dalam mencapai prestasi belajar yang tinggi. Meskipun banyak juga siswa yang memiliki motivasi untuk berprestasi yang tinggi. Siswa memiliki motivasi berprestasi tinggi kalau keinginan untuk sukses benar-benar berasal dari dalam diri sendiri. Siswa akan bekerja keras baik dalam diri sendiri maupun dalam bersaing dengan siswa lain.

Sehubungan dengan hal tersebut di atas, penulis merasa tertarik untuk mengadakan penelitian yang menyangkut korelasi motivasi belajar terhadap hasil 
belajar siswa pada Sekolah Dasar Negeri 3 Allakuang Kecamatan Maritengngae Kabupaten Sidenreng Rappang.

Berdasarkan latar belakang di atas, maka rumusan masalah dalam penelitian ini adalah: Apakah motivasi belajar berhubungan dengan hasil belajar siswa pada Sekolah Dasar Negeri 3 Allakuang Kecamatan Maritengngae Kabupaten Sidenreng Rappang.

\section{METODE PENELITIAN}

Berdasarkan tujuan yang akan dicapai dalam penelitian ini, maka data dianalisis secara deskriptif dan kuantitatif. Model analisis yang digunakan adalah sebagai berikut:

1. Analisis secara deskriptif mengenai korelasi motivasi belajar terhadap hasil belajar siswa pada Sekolah Dasar Negeri 3 Allakuang Kecamatan Maritengngae Kabupaten Sidenreng Rappang.

2. Metode Analisis Koefisien Regresi Linear untuk mengetahui pengaruh motivasi belajar terhadap hasil belajar siswa pada Sekolah Dasar Negeri 3 Allakuang Kecamatan Maritengngae Kabupaten Sidenreng Rappang, penulis menggunakan analisis koefisien regresi linear. Adapun rumus analisis regresi linear menurut Suharyadi (2009: 207) sebagai berikut:

$$
Y=a+b x
$$

\section{Dimana:}

$$
\begin{aligned}
& Y=\text { Hasil Belajar } \\
& a=\text { Konstanta } \\
& b=\text { Koefisien } \\
& X=\text { Motivasi Belajar } \\
& \text { Parameter a dan b digunakan persamaan: } \\
& b=\underline{n(\Sigma X Y)-(\Sigma X \Sigma Y)} \\
& n\left(\Sigma X^{2}\right)-(\Sigma X)^{2} \\
& a=\underline{\Sigma Y-b(X)} \\
& \quad n
\end{aligned}
$$

\section{Korelasi Product Moment}

Menurut Sugiyono (2005: 212), mengemukakan bahwa: “Korelasi Product Moment digunakan untuk mencari hubungan dan membuktikan hipotesis hubungan dua variable bila data kedua variable berbentuk interval atau rasio, dan sumber data dari dua variable atau lebih adalah sama “. Dihitung dengan rumus:

$$
r=\frac{\mathrm{n}\left(\sum \mathrm{xy}\right)-\left(\sum \mathrm{x}\right)\left(\sum \mathrm{y}\right)}{\left.\sqrt{\left[\mathrm{n}\left(\sum \mathrm{x}^{2}\right)\right.}-\left(\sum \mathrm{x}\right)^{2}\right]\left[\mathrm{n}\left(\sum \mathrm{y}^{2}\right)\left(\sum \mathrm{y}\right)^{2}\right]}
$$




\section{HASIL DAN PEMBAHASAN}

\section{Karakteristik Responden}

Karakteristik responden merupakan informasi yang sangat penting dan berguna bagi peneliti untuk mengetahui dan memahami identitas yang dimiliki responden. Informasi mengenai identitas responden terdiri atas; jenis kelamin, usia, dan jenjang pendidikan, merupakan informasi yang terkait dengan variabel dalam penelitian.

\section{Jenis Kelamin Responden}

Salah satu karakteristik responden yang memiliki daya tarik dan kekuatan untuk menghasilkan prestasi belajar adalah jenis kelamin.Kedua jenis kelamin tersebut masing-masing kelebihan dan kekurangan baik sebagai pria maupun sebagai wanita. Jumlah siswa tingkat VI dan sebagian dari tingkat V pada Sekolah Dasar Negeri 3 Allakuang Kecamatan Maritengngae Kabupaten Sidenreng Rappang pria dan wanita yang menjadi responden dalam penelitian ini dilihat pada Table 2 di bawah ini.

Tabel 7

Jenis Kelamin Responden

\begin{tabular}{|c|c|c|c|}
\hline No. & Jenis Kelamin & Jumlah & Persentase \\
\hline 1. & Pria & 26 & $59,09 \%$ \\
\hline 2. & Wanita & 18 & $40,91 \%$ \\
\hline & Jumlah & 44 & $100 \%$ \\
\hline
\end{tabular}

\section{Sumber: Hasil Penelitian}

Berdasarkan pada Tabel di atas menunjukkan bahwa jumlah siswa tingkat $\mathrm{V}$ dan VI pada Sekolah Dasar Negeri 3 Allakuang Kecamatan Maritengngae Kabupaten Sidenreng Rappang terdiri atas laki-laki sebanyak 26 orang (59,09\%) dan wanita sebanyak 18 orang (40,91\%).

Pengajaran merupakan alih transformasi ilmu pengetahuan dan teknologi yang berkaitan dengan peningkatan pengetahuan melalui proses pembelajaran baik secara formal maupun informal dengan maksud meningkatkan kemampuan dan kecerdasan individu baik kecerdasan intelektual (Intelectual Inteligence), kecerdasan emosional (Emotional Inteligence), dan kecerdasan spiritual (Spritual Inteligence), yang dapat menambah wawasan dan pemahaman tentang bagaimana melakukan sesuatu yang baik dan bermanfaat baik dirinya sendiri maupun terhadap orang lain dan lingkungannya. Secara teoritis seseorang yang memiliki kemampuan dan kecerdasan yang tinggi dan kemudian digunakan pada jalan yang benar dan bermanfaat pada orang banyak, maka yang bersangkutan akan mendapatkan paling sedikit dua penghasilan sekaligus, yang pertama adalah meningkatkan prestasinya dan kedua, memperoleh amal kebajikan. 
Seseorang yang memiliki prestasi yang baik berarti orang tersebut telah memiliki pengetahuan baik tentang teori dan konsep sekaligus berdampak pada perubahan perilaku dan sikap. Dengan demikian konsekuensi dari suatu pendidikan tersebut adalah bertujuan untuk melakukan perubahan dari sikap yang pesimis menjadi optimis, orang-orang yang ketika pada awalnya tidak mampu melakukan sesuatu menjadi orang yang mampu bahkan dapat meningkatkan prestasinya. Hal ini bisa di lakukan oleh seorang tenaga pengajar bagaimana mereka bisa memotivasi anak didiknya agar mampu meningkatkan prestasi belajarnya .

Dalam hubungannya dengan obyek penelitian ini maka yang dimaksud Prestasi merupakan nilai angkah yang menunjukan kualitas keberhasilan, sudah barang tentu semua siswa berhasil mencapai dengan terlebih dahulu mengikuti evaluasi yang diselenggarakan guru atau sekolah. Untuk mencapai prestasi maka diperlukan sifat dan tingkah laku seperti: aspirasi yang tinggi, aktif mengerjakan tugas tugas-tugas, kepercayaan yang tinggi, interaksi yang baik, kesiapan belajar dan sebagainya. Sifat dan ciri-ciri yang dituntut dalam kegiatan belajar itu hanya terdapat pada individu yang mempunyai motivasi yang tinggi, sedangkan yang mempunyai motivasi yang rendah tidak ada sehingga akan menghambat kegiatan belajarnya. Jadi secara teoritis motivasi akan berhubunggan dengan prestasi belajar yang dicapai siswa dalam proses pendidikan dan dalam proses peningkatan prestasinya. Dengan motivasi, diharapkan setiap pekerjaan yang dilakukan secara efektif dan efesien, sebab motivasi akan menciptakan kemauan untuk belajar secara teratur, oleh karena itu siswa harus dapat memanfaatkan setuasi dengan sebaik-baiknya. Banyak siswa yang belajar tetapi hasilnya kurang sesuai dengan yang diharapkan, sebab itu diperlukan jiwa motivasi, dengan motivasi seorang siswa akan mempunyai cara belajar dengan baik. Dengan demikian betapa besarnya peranan motivasi dalam menunjang keberhasilan belajar seorang siswa di sekolah.

Apabila seorang memiliki motivasi dan kebiasaan yang baik maka setiap usaha yang dilakukan akan memberikan hasil yang memuaskan, menurut Tadjab, motivasi belajar adalah keseluruhan daya penggerak di dalam diri siswa yang menimbulkan kegeiatan belajar, menjamin kelangsungan kegiatan itu demi mencapai suatu tujuan. Oleh karena itu yang penting bagaimana menciptakan kondisi tertentu agar siswa itu selalu butuh dan ingin terus belajar untuk mengembangkan potensi diri.

Belajar dengan motivasi dan terarah dapat menghindarkan diri rasa malas dan menimbulkan kegairahan siswa dalam belajar, pada akhirnya dapat meningkatkan daya kemampuan belajar siswa. Pada dasarnya prestasi belajar adalah akibat dari belajar, terutama belajar yang mempunyai motivasi tinggi. Jadi uraian diatas dapat disimpulkan bahwa motivasi belajar mempunyai hubungan erat 
dengan prestasi belajar. Semakin tinggi motivasi belajar siswa kemungkinan semakin besar peluang untuk mencapai prestasi yang baik atau tinggi.

Berdasarkan pada hasil angket yang disampaikan kepada 44 siswa sebagai responden (sampel penelitian) dengan kuesioner yang terdiri atas 20 butir pertanyaan pada variabel motivasi belajar dengan indikator:

1. Cita cita terdiri dari tiga pertanyaan .

2. Kemampuan belajar terdiri dari tiga pertanyaan.

3. Kondisi jasmani dan rohani terdiri dari empat pertanyaan.

4. Kondisi lingkungan terdiri dari tiga pertanyaan.

5. Unsur-unsur dinamis dalam belajar terdiri dari tujuh pertanyaan

Untuk variabel prestasi belajar terdiri dari 20 butir pertayaan dengan indikator sebagai berikut:

1. Informasi verbal terdiri dari lima pertanyaan

2. Keterampilan intelek terdiri dari lima pertanyaan

3. Strategi kognitif terdiri dari lima pertanyaan

4. Keterampilan motorik terdiri dari lima pertanyaa.

Berdasarkan penjelasan sebelumnya, maka pada tahap ini penulis mencoba menguji hipotesis yang telah diajukan pada Bab II yaitu diduga bahwa motivasi belajar berhubungan dengan prestasi belajar siswa pada Sekolah Dasar Negeri 3 Allakuang Kecamatan Maritengngae Kabupaten Sidenreng Rappang.

Tabel 8

Tabel Penolong Regresi dan Koefesien Korelasi

Pengaruh Motivasi Belajar Terhadap Prestasi Belajar Siswa Pada Sekolah Dasar Negeri 3 Allakuang Kecamatan Maritengngae Kabupaten Sidenreng Rappang

\begin{tabular}{|c|c|c|c|c|c|}
\hline Responden & $\begin{array}{c}\text { Motivasi } \\
\text { Belajar } \\
(\mathrm{X})\end{array}$ & $\begin{array}{c}\text { Prestasi Belajar } \\
\text { Siswa } \\
(\mathrm{Y})\end{array}$ & $\mathbf{X Y}$ & $\mathrm{X}^{2}$ & $\mathrm{Y}^{2}$ \\
\hline 1 & 4 & 3,95 & 15,8 & 16 & 15,6 \\
\hline 2 & 4,25 & 3,95 & 16,79 & 18,06 & 15,6 \\
\hline 3 & 4,15 & 4,25 & 17,64 & 17,22 & 18,06 \\
\hline 4 & 4,2 & 4,05 & 17,01 & 17,64 & 16,4 \\
\hline 5 & 4 & 4,1 & 16,4 & 16 & 16,81 \\
\hline 6 & 4,2 & 3,9 & 16,38 & 17,64 & 15,21 \\
\hline 7 & 4,05 & 3,9 & 15,78 & 16,4 & 15,21 \\
\hline 8 & 4,15 & 4,05 & 16,81 & 17,22 & 16,4 \\
\hline 9 & 4,25 & 3,95 & 16,79 & 18,06 & 15,6 \\
\hline 10 & 4,15 & 4 & 16,6 & 17,22 & 16 \\
\hline 11 & 4,05 & 3,95 & 15,98 & 16,4 & 15,6 \\
\hline 12 & 4 & 3,8 & 15,2 & 16 & 14,44 \\
\hline 13 & 4,05 & 3,95 & 15,98 & 16,4 & 15,6 \\
\hline 14 & 4,2 & 4 & 16,8 & 17,64 & 16 \\
\hline
\end{tabular}




\begin{tabular}{|c|c|c|c|c|c|}
\hline 15 & 4,25 & 3,85 & 16,36 & 18,06 & 14,82 \\
\hline 16 & 4,05 & 3,95 & 15,98 & 16,4 & 15,6 \\
\hline 17 & 3,85 & 4 & 15,4 & 14,82 & 16 \\
\hline 18 & 4,1 & 3,8 & 15,58 & 16,81 & 14,44 \\
\hline 19 & 4,25 & 4,05 & 17,21 & 18,06 & 16,4 \\
\hline 20 & 4 & 3,8 & 15,2 & 16 & 16 \\
\hline 21 & 4,15 & 3,95 & 16,4 & 17,22 & 15,6 \\
\hline 22 & 4,1 & 4,05 & 16,61 & 16,81 & 16,4 \\
\hline 23 & 3,9 & 4 & 15,6 & 15,21 & 16 \\
\hline 24 & 3,65 & 3,6 & 13,14 & 13,32 & 12,96 \\
\hline 25 & 3,7 & 4 & 14,8 & 13,69 & 16 \\
\hline 26 & 3,75 & 4 & 15 & 14,06 & 16 \\
\hline 27 & 3,85 & 3,9 & 15,02 & 14,82 & 15,21 \\
\hline 28 & 3,8 & 3,95 & 15,01 & 14,44 & 15,6 \\
\hline 29 & 3,85 & 4 & 15,4 & 14,82 & 16 \\
\hline 30 & 3,6 & 3,7 & 13,32 & 12,96 & 13,69 \\
\hline 31 & 4,05 & 3,6 & 14,58 & 16.4 & 16,4 \\
\hline 32 & 4,05 & 3,8 & 15,39 & 16,4 & 16,4 \\
\hline 33 & 4,2 & 3,8 & 15,96 & 17,64 & 17,64 \\
\hline 34 & 4,1 & 4,1 & 16,81 & 16,81 & 16,81 \\
\hline 35 & 3,85 & 3,6 & 13,86 & 14,82 & 14,82 \\
\hline 36 & 4 & 3,95 & 15,8 & 16 & 15,6 \\
\hline 37 & 4,25 & 4 & 17 & 18,06 & 18,06 \\
\hline 38 & 4,05 & 3,95 & 15,98 & 16,4 & 15,6 \\
\hline 39 & 4,35 & 3,8 & 16,53 & 18,92 & 17,64 \\
\hline 40 & 4,2 & 3,85 & 16,17 & 17,64 & 14,82 \\
\hline 41 & 4,1 & 3,95 & 16,2 & 16,81 & 15,6 \\
\hline 42 & 3,7 & 3,9 & 14,4 & 13,69 & 15,21 \\
\hline 43 & 4,15 & 3,85 & 15,98 & 17,22 & 14,82 \\
\hline 44 & 3,95 & 3,8 & 15,01 & 15,6 & 16,4 \\
\hline $\mathrm{N}=44$ & $\Sigma X=177,55$ & $\sum Y 172,35$ & $\begin{array}{c}\sum X Y \\
695,66\end{array}$ & $\begin{array}{c}\Sigma X^{2} \\
701,41\end{array}$ & $\begin{array}{c}\sum Y^{2} \\
695,07\end{array}$ \\
\hline
\end{tabular}

Sumber : Data diolah

Untuk mengetahui tingkat hubungan motivasi belajar terhadap prestasi belajar siswa pada Sekolah Dasar Negeri 3 Allakuang Kecamatan Maritengngae Kabupaten Sidenreng Rappang, maka penulis menganalisis menggunakan persamaan regresi linier sederhana sebagai berikut :

$$
\text { Dik: } \quad \begin{aligned}
& \Sigma X=177,55 \\
& \\
& \Sigma Y=172,35 \\
& \Sigma X Y=695,66 \\
& \Sigma X^{2}=701,41 \\
& \Sigma Y^{2}=695,07
\end{aligned}
$$




$$
N=44
$$

Berdasarkan data pada tabel di atas, maka dapat dihitung nilai b yaitu:

$$
Y=a+b x
$$

Dimana:

$$
\begin{aligned}
& \mathrm{Y}=\text { Hasil Belajar } \\
& \mathrm{a}=\text { Konstanta } \\
& \mathrm{b}=\text { Koefisien } \\
& \mathrm{X}=\text { Motivasi Belajar }
\end{aligned}
$$

Parameter a dan b digunakan persamaan:

$$
\begin{array}{cc}
b=\frac{n(\Sigma X Y)-(\Sigma X \Sigma Y)}{n\left(\Sigma X^{2}\right)-(\Sigma X)^{2}} \\
b=\frac{44 \cdot(695,66)-(177,55) \cdot(172,35)}{44 \cdot(701,41)-(177,55)} \\
b=\frac{(30.609,04)-(30.600,74)}{(30.862,04)-(177,55)} \\
b=\quad \frac{83}{(30.684,49)} \\
b=\quad 0,00027
\end{array}
$$

Untuk menentukan parameter a dapat dihitung dengan menggunakan persamaan:

$$
a=\frac{\Sigma Y-b(X)}{n}
$$

$$
\begin{aligned}
& a=\frac{172,35-(0,00027) \cdot(177,55)}{44} \\
& a=\frac{172,35-0,047}{44} \\
& a=\frac{172,30}{44} \\
& a=3,91
\end{aligned}
$$

Jadi berdasarkan perhitungan di atas, maka persamaan regresi adalah $Y=3,91+$ 0,0027 . Hasil perhitungan diatas dapat dijelaskan bahwa setiap 1 satuan nilai motivasi dinaikkan maka akan meningkatkan prestasi belajar siswa sebesar 0,27.

Untuk mengetahui tingkat korelasi atau keeratan hubungannya antara motivasi belajar terhadap prestasi belajar siswa pada Sekolah Dasar Negeri 3 Allakuang Kecamatan Maritengngae Kabupaten Sidenreng Rappang, maka penulis menganalisis menggunakan rumus korelasi sebagai berikut:

$$
r=\frac{n \sum X Y-\left(\sum X\right)\left(\sum Y\right)}{\sqrt{n \sum X^{2}-}(X)^{2} \sqrt{n \sum_{Y} 2-\left(\sum_{Y}\right)^{2}}}
$$

Koefisien korelasi mendekati satu kenyataan kuat hubungan ketergantungannya atau signifikan.

Berdasarkan tabel di atas, dapat dicari koefisien korelasi dengan cara:

Dik: $\quad \Sigma X=177,55$

$$
\begin{aligned}
& \Sigma Y=172,35 \\
& \Sigma X Y=695,66 \\
& \Sigma X^{2}=701,41
\end{aligned}
$$




$$
\begin{aligned}
& \Sigma Y^{2}=695,07 \\
& \mathrm{~N}=44 \\
& r=\frac{n \sum X Y-\left(\sum X\right)\left(\sum Y\right)}{\sqrt{n \sum X^{2}-(X)^{2} \sqrt{n \sum_{Y} 2-\left(\sum_{Y}\right)^{2}}}} \\
& (44) \times(695,66)-(177,55) \times(172,35) \\
& r=\overline{\left.\left.\sqrt{ }(44) \times(701,41)-(177,55)^{2}\right) \times \sqrt{ }(44) \times(695,07)-(172,35)^{2}\right)} \\
& (30.609,04)-(30.600,74) \\
& r=\sqrt{(30.862,04-31.524) \cdot \sqrt{ }(30.583,08-29.704,52)} \\
& (8,3) \\
& r=\overline{(\sqrt{ }(661,96) \sqrt{ }(878,56)} \\
& (8,3) \\
& r=\overline{(25,72 \times 29,64)} \\
& r=\frac{(8,3)}{(762,34)} \\
& r=0,010 \\
& r=0,10
\end{aligned}
$$

Berdasarkan hasil perhitungan koefisien korelasi $r=0,10$ atau atau berada di daerah postif, ini menunjukkan bahwa antara motivasi belajar dengan prestasi belajar siswa positif atau, artinya bahwa kenaikan nilai x (Motivasi belajar) terjadi bersama kenaikan nilai y (Prestasi belajar siswa), persamaan di atas menunjukkan bahwa untuk koefisien regresi $X$ sebesar 0,10 yang mempunyai arti bahwa setiap penambahan satu poin motivasi belajar maka prestasi belajar siswa akan bertambah 0,10 . Hipotesis dalam penelitian ini adalah terdapat hubungan positif antara motivasi belajar dengan hasil belajar siswa pada Sekolah Dasar Negeri 3 Allakuang Kecamatan Maritengngae Kabupaten Sidenreng Rappang.

Keeratan hubungan antara Motivasi Belajar dengan Prestasi belajar siswa adalah sebesar 0,10 atau $10 \%$. Tanda positif pada koefisien korelasi menunjukkan ada hubungan searah namun hubungan korelasinya rendah, artinya apabila guru memberikan dorongan motivasi belajar kepada siswa akan mempengaruhi tingkat kenaikan prestasinya.

Koefisien Determinasi $\left(\mathrm{r}^{2}\right)$ adalah 0,001 artinya besarnya pengaruh motivasi belajar terhadap prestasi belajar siswa adalah sebesar $10 \%$. Sisanya sebesar $90 \%$ 
merupakan pengaruh variabel bebas lainnya yang tidak dibahas dalam penelitian ini.

Berdasarkan hasil analisis diperoleh nilai koefisien korelasi ( $r$ ) sebesar 0,10. Nilai koefisien korelasi tersebut signifikan pada taraf signifikansi 0,05 ini menunjukan bahwa "terdapat hubungan yang positif antara motivasi belajar siswa dengan prestasi belajar siswa pada Sekolah Dasar Negeri 3 Allakuang Kecamatan Maritengngae Kabupaten Sidenreng Rappang, sehingga hipotesis awal yang menyatakan bahwa motivasi belajar berpengaruh terhadap prestasi belajar siswa di terima. Nilai Koefisien korelasi 0,10 juga menunjukkan bahwa indeks kuatnya hubungan korelasi X (Motivasi belajar) terhadap Y (prestasi belajar) berada dalam kategori sangat rendah. Hal ini sejalan dengan apa yang dikemukakan atau menggunakan pedoman untuk memberikan interpretasi koefisien korelasi menurut Sugiyono (2000) sebagai berikut:

$\begin{array}{rll}\text { Interval } & & \begin{array}{c}\text { Tingkat hubungan } \\ 0,00-0,199\end{array} \\ 0,20-0,399 & : & \text { Sangat rendah } \\ 0,40-0,599 & : & \text { Sedah } \\ 0,60-0,799 & : & \text { Kuat } \\ 0,80-1,000 & : & \text { Sangat Kuat }\end{array}$

Motivasi belajar dari hasil penelitian ini telah dibuktikan mampu memprediksi prestasi belajar siswa sebesar $10 \%$. Hal ini berarti bahwa motivasi belajar merupakan salah satu faktor penentu keberhasilan belajar siswa yang dapat menentukan bersama dengan factor lainnya seperti ketersediaan saranaprasarana, metode pembelajaran, dan lain sebagainya. Dikarenakan motivasi menjadi penggerak sekaligus pemberi arah kegiatan belajar, sehingga tujuan yang dikehendaki oleh subjek belajar dapat tercapai secara maksimal.

Walaupun demikian, hasil penelitian ini tentunya bukan berarti bahwa pengaruh faktor lain seperti faktor sosial ekonomi, jenis kelamin, tingkat IQ, dan lain sebagainya dapat diabaikan begitu saja. Karena dari hasil kajian beberapa penelitian tentang prestasi belajar ternyata juga membuktikan bahwa status sosial ekonomi dan jenis kelamin juga sangat berpengaruh terhadap prestasi belajar siswa.

Siswa yang memiliki motivasi yang kuat dalam mengikuti proses pembelajaran di kelas terlihat penuh semangat, antusias, memiliki rasa ingin tahu yang tinggi, aktif dalam pembelajaran, rajin dalam mengerjakan tugas-tugas yang diberikan guru, sehingga mereka memiliki daya tahan yang cukup lama dalam menyelesaikan studi, dibandingkan dengan siswa yang kurang memiliki motivasi. Siswa yang motivasinya tergolong rendah ini biasanya menunjukkan sikap bermalasan, mengantuk, dan perhatiannya terbagi kemana-mana di saat proses belajar sedang berlangsung. Kemauan tersebut tampak pada usaha seseorang untuk mengerjakan sesuatu. Seseorang yang memiliki motivasi tinggi akan lebih 
keras berusaha daripada seseorang yang memiliki motivasi rendah. Tetapi motivasi bukanlah perilaku. la merupakan proses internal yang kompleks yang tidak bisa diamati secara langsung, melainkan bisa dipahami melalui kerasnya usaha seseorang dalam mengerjakan sesuatu.

Secara teknis, proses dasar motivasional seseorang berawal dari adanya kekurangan dalam diri seseorang (innerdeficiencies) atau kebutuhan yang belum terpenuhi (unsatisfied needs). Kekurangan ini akan menimbulkan ketegangan (tension) yang mendorong seseorang untuk bertindak (drive). Selanjutnya dorongan ini membangkitkan seseorang untuk bertindak (behavior) untuk mencapai tujuan tertentu. Apabila tujuan ini tercapai berarti kekurangan atau kebutuhannya terpenuhi (satisfied need) dan sekaligus menghilangkan ketegangan. Sebaliknya, apabila tujuan ini belum tercapai, berarti kebutuhannya belum juga terpenuhi, maka akan timbul perilaku yang tidak tepat (inappropriate) dalam bentuk penyerangan (aggression) atau ketidakhadiran (absenteeism).

Begitupun terhadap para siswa pada Sekolah Dasar Negeri 3 Allakuang Kecamatan Maritengngae Kabupaten Sidenreng Rappang, memberikan motivasi sangat perlu untuk dilakukan, agar siswa dapat mampu termotivasi dalam mengembangkan dirinya dan mampu meningkatkan prestasi belajarnya .

\section{KESIMPULAN DAN SARAN}

\section{Kesimpulan}

Berdasarkan hasil penelitian dan pembahasan yang telah di kemukakan sebelumnya, maka dapatlah ditarik kesimpulan sebagai berikut:

Berdasarkan hasil penelitian menunjukkan motivasi belajar berhubungan positif dengan prestasi belajar siswa, namun hubungannya lemah karna hasil pembahasan menunjukkan hubungan antara motivasi belajar dengan hasil belajar siswa sebesar 0,10 atau 10\%. Hal in menunjukkan bahwa bila motivasi belajar meningkat berarti ada kecenderungan bahwa hasil belajar juga dapat meningkat , demikian pula dengan sebaliknya.

\section{Saran}

Berdasarkan simpulan yang telah dikemukakan di atas dan untuk meningkatkan prestasi belajar siswa secara efektif efesien, maka ada beberapa saran dari penulis yang mungkin bermanfaat bagi sekolah dalam rangka prestasi belajar siswa pada Sekolah Dasar Negeri 3 Allakuang Kecamatan Maritengngae Kabupaten Sidenreng Rappang sebagai berikut:

1. Meskipun pemberian motivasi belajar berpengaruh, namun pihak sekolah harus tetap memberikan peningkatan kualitas pendidikan lewat pengayaan dalam rangka meningkatkan prestasi secara berkala kepada para siswa yang dianggap belum memiliki kemampuan yang memadai atau kemampuan yang kurang.

2. Mendorong para siswa secara optimal berdasarkan minat dan bakatnya untuk bisa dikembangkan kearah yang lebih baik lagi. 


\section{DAFTAR PUSTAKA}

Abin Syamsuddin, 2001. Prestasi kerja: Penilaian dan Pengukuran. Penerbit Harvarindo, Jakarta.

Arikunto, 2003. Peningkatan Keterampilan Dalam Pengajaran. Penerbit Mandar. Maju, Jakarta.

Afifuddin, 2008.Penempatan SDM dalam Tinjauan Kualitas Pendidikan. Penerbit Harvarindo, Jakarta.

Dimyanti, 2004. Human Resource Management InQuality and Quantity. $\quad$ http; // humanresouce.com.

Hamdu, 2011. Hubungan Motivasi Belajar Dengan Hasil Belajar.http: // humanresource.com.

Handoko, Hani T. 2001. Manajemen Sumber Daya Manusia. Penerbit BPFE, Yogyakarta.

Hasan, Hamdah, 2003. Peranan Pendidikan terhadap Kualitas SDM. Penerbit Bina IImu, Solo.

Hasibuan P. Malaju, 2005. Manajemen Sumber Daya Manusia. Penerbit RinekaCipta, Jakarta.

Hatta, Darmadji, 2000. Kemandirian SDM dalam Pengembangan Skill Kerja. Penerbit Pustakajaya, Jakarta.

Makmun .2001. Psikologi Pendidikan, Penerbit elang IImu persada Jakarta.

Mulyadi, 2011. Manajemen Pendidikan. Penerbit Raja Grafindo Prsada, Jakarta.

Mangkunegara, A.A. Anwar Prabu. 2001. Manajemen Sumber Daya Manusia.PT. Refika Aditama - Bandung.

Martopo, Anshary, 2004. Peningkatan Kompetensi menuju SDM Berkualitas. Penerbit Tarsito, Bandung.

Mulawarman, 2003. Sistem Pendidikan Berbasis Pelatihan Kompetensi dan Intelegensi. Penerbit Gramedia Pustaka, Jakarta.

Mulianto, Darman, 2005. Pelatihan: Suatu Pencerahan Kualitas SDM. Penerbit Tarsito, Bandung.

Puspitasari, 2012. Strategi Belajar Mengajar. Salemba Empat. Surabaya.

Rahmat Saleh, 2011. Kurikulum dan Pembelajaran. Penerbit Andi, Jogyakarta.

Riswanto, 2008. Belajar dan Faktor- Faktor Yang Mempengaruhinya. Bumi Aksara . Jakarta.

Satriya Sutopo, 2007. Kualitas sumber daya Manusia dalam Penguasan Dunia kerja.Penerbit elang IImu persada Jakarta.

Sardiman, 2008. Metode Pendekatan Pengajaran Berkualitas. Penerbit Andi, Jogyakarta. 
Sudjana , 2009. Prestasi kerja Dalam Prestasi kerja Organisasi Modern. Penerbit Erlangga, Jakarta.

Soetarjo, Ahmadi, 2004. Sistem Pendidikan Peningkatan Kompetensi Individu. Penerbit Raja wali Press, Jakarta.

Sudjana, 1999. Metodologi Penelitian Kulitatif dan Kuantitatif. Penerbit Balai Pustaka Jakarta.

Sugiyono, 2005. Pokok Pokok Materi Statistik . Penerbit Andi, Jakarta.

Sulastomo, 2000. Sosialisasi Prestasi Kerja Kepegawaian. Penerbit Gunung Agung Jakarta.

Tabrani. A. 2010. Pendidikan Dalam Pengalian Potensi Personal. Penerbit Salemba Empat, Jakarta.

Tirtonegoro. 2004. Motivasi Dalam Pendidikan. Penerbit Tarsito, Bandung

Tadjab, 2010. Peningkatan Keterampilan SDM. Penerbit Mandar. Maju, Jakarta.

Wardoyo, Darmin, 2005. Tingkat Pendidikan Implementasi Dunia Kerja Penerbit. Selemaba Empat Jakarta.

Wasty, 2004. Aplikasi Pelatihan Berbasis Kompetensi. Penerbit Salemba Empat, Jakarta. 